Session 1522

\title{
The Fuel Cell - An Ideal Chemical Engineering Undergraduate Experiment
}

\author{
Jung-Chou Lin, H. Russel Kunz, James M. Fenton, Suzanne S. Fenton \\ University of Connecticut
}

\begin{abstract}
Fuel cell based experiments embody principles in electrochemistry, thermodynamics, kinetics and transport and are ideally suited for the chemical engineering curricula. Experiments using a hydrogen proton exchange membrane (PEM) fuel cell have been developed for the chemical engineering undergraduate laboratory. The experiments allow students to study the principles of fuel cell operation and familiarize themselves with fuel cell performance as a function of oxidant composition and operating temperature. Experimental data can be fit to a simple model from which ohmic losses, kinetic parameters and limiting current density (mass transfer limitations) can be estimated and compared to measured or theoretical values.
\end{abstract}

\section{Introduction}

Because of their increasing viability as environmentally friendly energy sources and high chemical engineering content, fuel cell experiments have been developed for the chemical engineering undergraduate laboratory. A proton exchange membrane (PEM) fuel cell was chosen for these experiments due to inherent advantages including use of a solid polymer electrolyte that reduces corrosion problems, a low operating temperature that allows quick startup, zero toxic emissions and fairly good performance compared to other fuel cells.

A cross-sectional diagram of a single-cell PEM fuel cell is shown in Figure 1. The proton exchange membrane $\left(\mathrm{Nafion}^{\circledR}\right)$ is in contact with the anode catalyst layer (shown on the left) and a cathode catalyst layer (shown on the right). Each catalyst layer is in contact with a gas diffusion layer. The membrane, catalyst layers and the gas diffusion layers make up what is called the membrane-electrode-assembly (MEA).

Fuel (hydrogen in this figure) is fed into the anode side of the fuel cell. Oxidant (oxygen, either in air or as a pure gas) enters the fuel cell through the cathode side. Hydrogen and oxygen are fed through flow channels and diffuse through gas diffusion layers to the catalyst on their respective sides of the MEA. Activated by the catalyst in the anode, hydrogen is oxidized to form protons and electrons. The protons move through the proton exchange membrane and the electrons travel from the anode through an external circuit to the cathode. At the cathode catalyst, oxygen reacts with the protons that move through the membrane and the electrons that travel through the circuit to form water and heat.

A general review of PEM fuel cell technology and basic electrochemical engineering principles can be found in references [1]-[7]. 
Figure 1. PEM Fuel Cell Cross Section

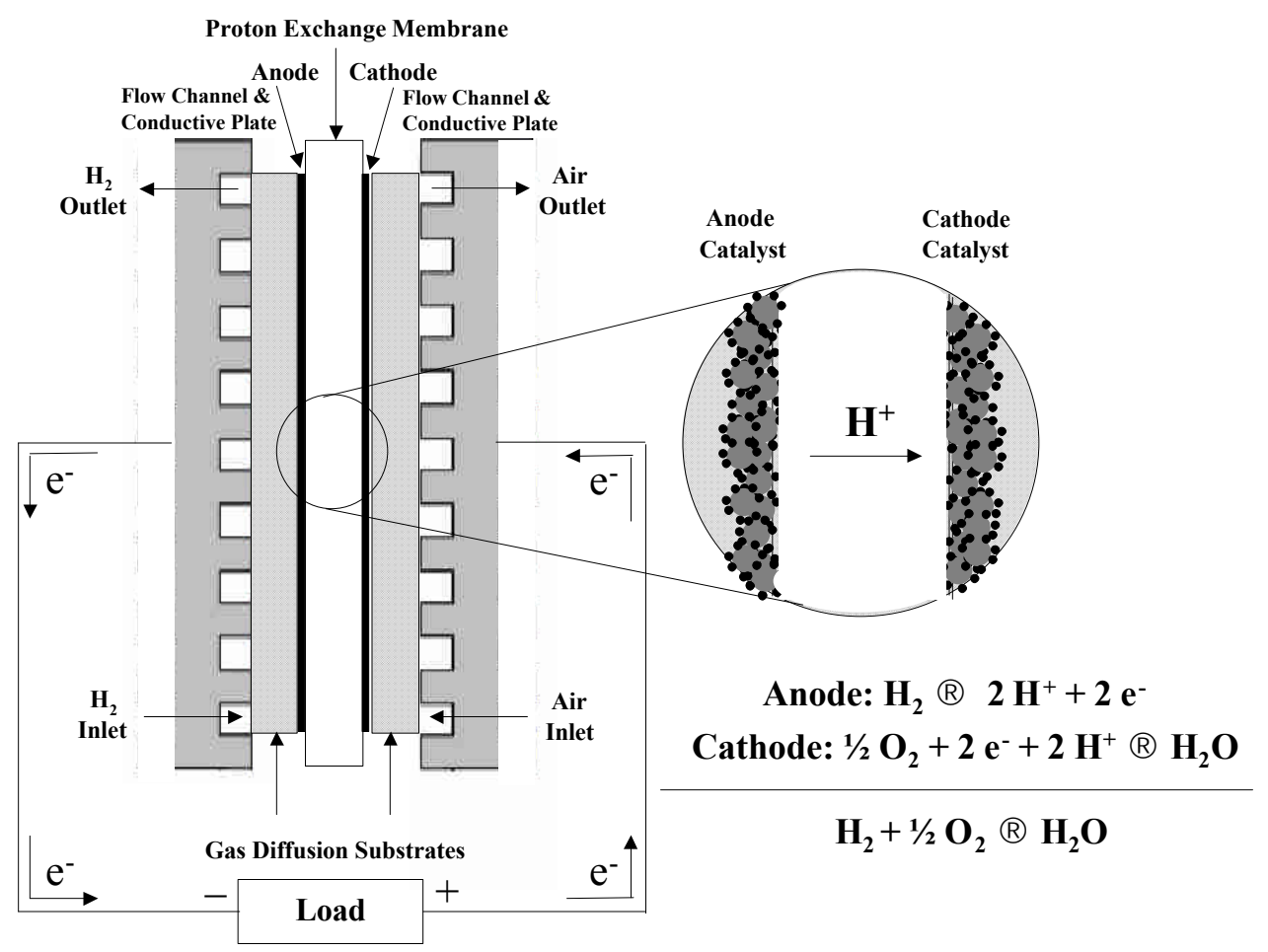

\section{Objectives}

The objectives of the fuel cell experiment are:

1. To familiarize students with the working principles and performance characteristics of the PEM fuel cell

2. To demonstrate the effect of oxygen concentration and temperature on fuel cell performance

3. To fit experimental data to a simple empirical model

Students will measure voltage and membrane internal resistance as a function of operating current at various oxygen concentrations and temperatures; generate current density vs. voltage performance curves; and calculate cell efficiency, reactant utilization, and power density. Current density is defined as the current produced by the cell divided by the active area of the membrane electrode assembly (MEA). By fitting their current density vs. voltage data to a simple empirical model, ohmic, activation (kinetic) and concentration (transport) polarization losses can be estimated and compared to experimental or theoretical values.

\section{Background}

The performance of a fuel cell can be characterized by its

1. current density vs. voltage curve as shown in Figure 2,

2. efficiency,

3. reactant utilization (ratio of moles of fuel consumed to moles of fuel fed), and

4. power density (ratio of power produced by a single cell to the area of the cell MEA). 
Only current density vs. voltage characteristics are discussed in this publication. A manuscript for publication in CEE will include an evaluation of efficiency, reactant utilization and power density.

\section{Current Density-Voltage Curve}

Since a fuel cell is a device that facilitates the direct conversion of chemical energy to electricity and water, the ideal or best attainable performance of a fuel cell is dictated only by the thermodynamics of the electrochemical reactions that occur (a function of the reactants and products). The electrochemical reactions in a hydrogen/oxygen fuel cell are shown in Equations (1) and (2).

$$
\begin{array}{ll}
\text { Anode Reaction: } & \mathrm{H}_{2} \rightarrow 2 \mathrm{H}^{+}+2 \mathrm{e}^{-} \\
\text {Cathode Reaction: } & 1 / 2 \mathrm{O}_{2}+2 \mathrm{H}^{+}+2 \mathrm{e}^{-} \rightarrow \mathrm{H}_{2} \mathrm{O}
\end{array}
$$

The reversible (i.e. maximum) standard potential $\mathrm{E}^{\mathrm{o}}$ for the $\mathrm{H}_{2} / \mathrm{O}_{2}$ cell reaction is 1.229 volts per mole of hydrogen (at $25{ }^{\circ} \mathrm{C}$, unit activity for the species, liquid water product) as determined by the change in Gibbs free energy. The reversible standard potential for the hydrogen/oxygen cell is indicated on the current density-voltage diagram in Figure 2 as the green horizontal line.

Figure 2. Fuel Cell Performance Curves

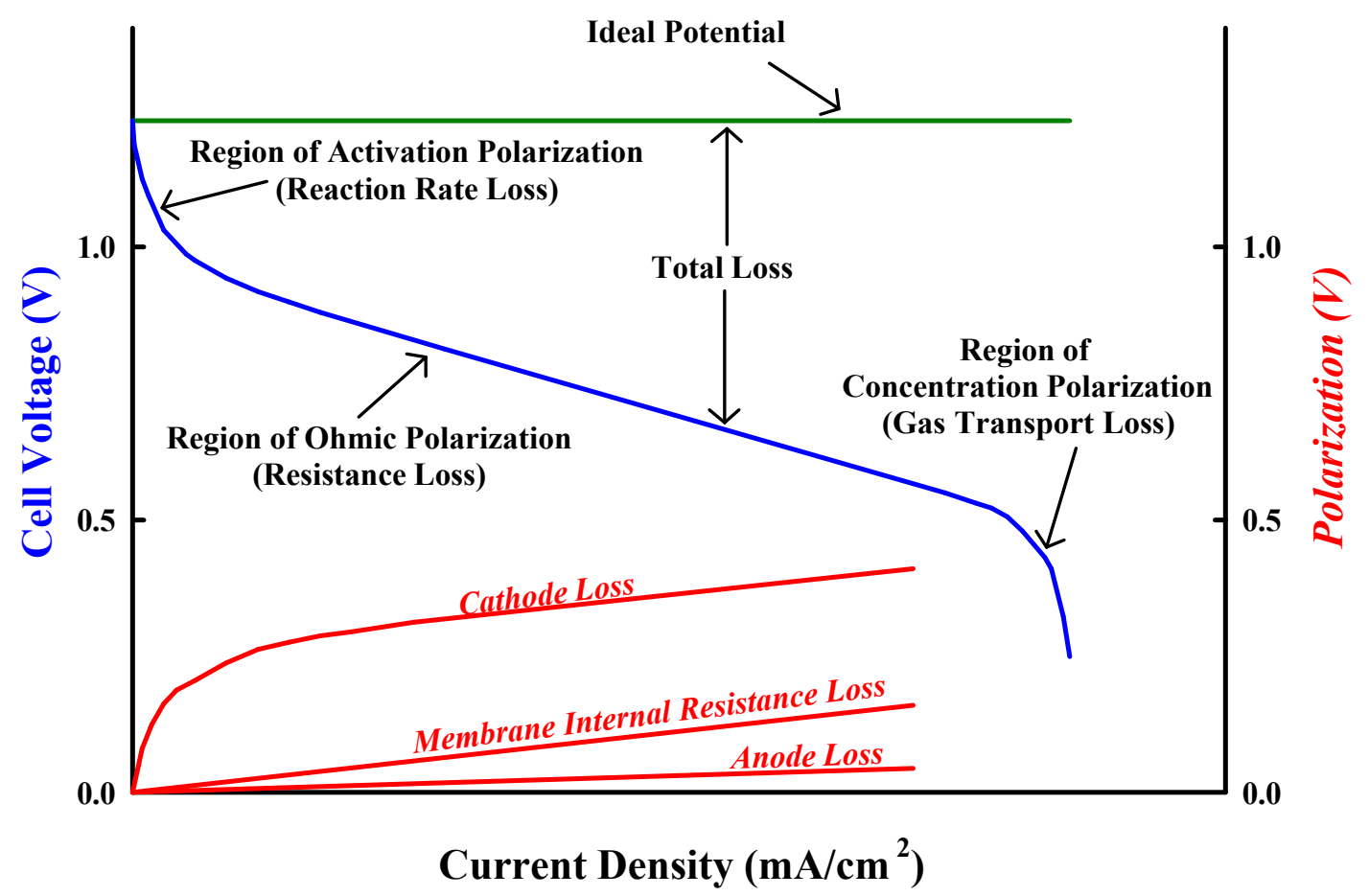

When a load (external resistance) is applied to the cell, non-equilibrium exists and a current flows. There is a trade off between current and voltage at non-equilibrium (non-ideal) 
conditions. The current density-voltage relationship for a given fuel cell (geometry, catalyst/electrode characteristics, and electrolyte/membrane properties) and operating conditions (concentration, flow rate, pressure, temperature, and relative humidity) is a function of kinetic, ohmic, and mass transfer resistances. The current density vs. voltage curve, shown in blue in Figure 2, is referred to as the polarization curve. Deviations between the ideal equilibrium potential and the polarization curve provide a measure of fuel cell efficiency. At their current level of development, Nafion ${ }^{\circledR}$ membrane PEM fuel cells can produce approximately $1 \mathrm{~A} / \mathrm{cm}^{2}$ current density at $0.6 \mathrm{~V}$, corresponding to a cell efficiency of $50 \%$.

Kinetic Limitations- Performance loss resulting from slow reaction kinetics at either/both the cathode and anode surfaces is called activation polarization $\left(\eta_{\text {act,c }} \& \eta_{\text {act,a }}\right)$. Activation polarization is related to the activation energy barrier between reacting species and is primarily a function of temperature, pressure, concentration, and electrode properties. Competing reactions can also play a role in activation polarization.

Kinetic resistance dominates the low current density portion of the polarization curve, where deviations from equilibrium are small. At these conditions, reactants are plentiful (no mass transfer limitations) and the current is so small that ohmic (iR) losses are negligible. The Tafel Equation describes the current density-voltage polarization curve in this region.

$$
\eta_{\text {act }}=\mathrm{B} \log |\mathrm{i}|-\mathrm{A}
$$

where $\eta_{\text {act }}$ is activation polarization (mv), i is current density $\left(\mathrm{mA} / \mathrm{cm}^{2}\right)$ and constants $A$ and B are kinetic parameters ( $\mathrm{B}$ is often called the Tafel slope ${ }^{[6]}$. As shown in Figure 2, the kinetic loss at the cathode, $\eta_{\text {act,c }}$, (the reduction of $\mathrm{O}_{2}$ to form water) is much greater than kinetic loss at the anode, $\eta_{\text {act,a }}$, in the $\mathrm{H}_{2} / \mathrm{O}_{2}$ cell.

Ohmic Limitations- Performance loss due to resistance to the flow of current in the electrolyte and through the electrodes is called ohmic polarization $\left(\eta_{\mathrm{ohm}}\right)$. Ohmic polarization is described using Ohm's Law $(\mathrm{V}=\mathrm{iR})$, where $\mathrm{i}$ is current density $\left(\mathrm{mA} / \mathrm{cm}^{2}\right)$ and $\mathrm{R}$ is resistance $\left(\Omega-\mathrm{cm}^{2}\right)$, and dominates the linear portion of the current density-voltage polarization curve as shown in Figure 2. Improving the ionic conductivity of the solid electrolyte separating the two electrodes can reduce ohmic losses.

Transport Limitations- Concentration polarization $\left(\eta_{\text {conc,c }} \& \eta_{\text {conc,a }}\right)$ occurs when a reactant is consumed on the surface of the electrode forming a concentration gradient between the bulk gas and the surface. Transport mechanisms within the gas diffusion layer and electrode structure include the convection/diffusion and/or migration of reactants and products $\left(\mathrm{H}_{2}, \mathrm{O}_{2}, \mathrm{H}^{+}\right.$ions, and water) into and out of catalyst sites in the anode and cathode. Transport of $\mathrm{H}^{+}$ions through the electrolyte is regarded as ohmic resistance (mentioned above). Concentration polarization is affected primarily by concentration and flow rate of the reactants fed to their respective electrodes, the cell temperature, and the structure of the gas diffusion and catalyst layers.

The mass transfer-limiting region of the current density versus voltage polarization curve is apparent at very high current density. Here, increasing current density results in a depletion of 
reactant immediately adjacent to the electrode. When the current is increased to a point where the concentration at the surface falls to zero, a further increase in current is impossible. The current density corresponding to zero surface concentration is called the limiting current density, and is observed in Figure 2 at $\sim 1200 \mathrm{~mA} / \mathrm{cm}^{2}$ as the polarization curve becomes vertical at high current density.

The actual cell voltage $\mathrm{V}$ at any given current density can be represented as the reversible potential minus the activation, ohmic and concentration losses as expressed in Equation 4.

$$
\mathrm{V}=\mathrm{E}-\left(\eta_{\mathrm{act}, \mathrm{c}}+\eta_{\mathrm{act}, \mathrm{a}}\right)-\mathrm{iR}-\left(\eta_{\text {conc,c }}+\eta_{\text {conc,a }}\right)
$$

$\mathrm{E}$ is the reversible cell potential at operating conditions (i.e. "non-standard" temperatures and concentrations), calculable using thermodynamic relations including the Nernst Equation. Note that activation $\left(\eta_{\text {act,c, }}, \eta_{\text {act,a }}\right)$ and concentration $\left(\eta_{\text {conc,c }}, \eta_{\text {conc,a }}\right)$ losses occur at both electrodes, however anode losses are generally much smaller than cathode losses for the $\mathrm{H}_{2} / \mathrm{O}_{2}$ cell and are neglected. Ohmic loses occur mainly in the solid electrolyte membrane. Current fuel cell research is focused on reducing kinetic, ohmic and transport polarization losses.

\section{Experimental Equipment, Procedure, and Implementation}

The experiments presented here are designed to give the experimenter a "feel" for fuel cell operation and to demonstrate temperature and concentration effects on fuel cell performance. The manipulated variables are cell temperature, concentration of oxygen fed to the cathode, and current. Flow rates are held constant and all experiments are performed at 1 atm pressure. The measured variables are voltage and resistance, from which polarization curves are generated and fuel cell performance evaluated. A simple empirical model can be fit to the data, allowing students to estimate ohmic resistance, kinetic parameters, and limiting current density. Table 1 summarizes the conditions investigated in this study.

Table 1. Experimental Conditions

\begin{tabular}{|c|c|c|c|c|c|}
\hline \multicolumn{3}{|c|}{ Anode Feed } & \multicolumn{3}{c|}{ Cathode Feed } \\
\hline $\begin{array}{c}\text { Temp } \\
\left({ }^{\circ} \mathrm{C}\right)\end{array}$ & $\begin{array}{c}\text { Flow rate } \\
(\mathrm{ml} / \mathrm{min})\end{array}$ & $\begin{array}{c}\text { Dry basis } \\
\text { Composition } \\
(\text { Mole } \%)\end{array}$ & $\begin{array}{c}\text { Temp } \\
\left({ }^{\circ} \mathrm{C}\right)\end{array}$ & $\begin{array}{c}\text { Flow rate } \\
(\mathrm{ml} / \mathrm{min})\end{array}$ & $\begin{array}{c}\text { Dry basis } \\
\text { Composition } \\
(\mathrm{Mole} \%)\end{array}$ \\
\hline 80 & 98 & $100 \% \mathrm{H}_{2}$ & 80 & 376 & $100 \% \mathrm{O}_{2}$ \\
\hline 80 & 98 & $100 \% \mathrm{H}_{2}$ & 80 & 376 & $\begin{array}{c}\text { Air - } \\
21 \% \mathrm{O}_{2} \text { in } \mathrm{N}_{2}\end{array}$ \\
\hline 80 & 98 & $100 \% \mathrm{H}_{2}$ & 80 & 376 & $10.5 \% \mathrm{O}_{2}$ in $\mathrm{N}_{2}$ \\
\hline 80 & 98 & $100 \% \mathrm{H}_{2}$ & 80 & 376 & $5.25 \% \mathrm{O}_{2}{\text { in } \mathrm{N}_{2}}$ \\
\hline 18 & 98 & $100 \% \mathrm{H}_{2}$ & 18 & 376 & $100 \% \mathrm{O}_{2}$ \\
\hline
\end{tabular}




\section{Equipment}

A schematic diagram of experimental setup is shown in Figure 3. The fuel cell test stand used in these experiments was assembled in-house. Completely assembled systems can be purchased from Scribner Associates, Inc. (www.scribner.com), Lynntech Inc. (www.lynntech.com), ElectroChem Inc. (www.fuelcell.com), and TVN (www.tvnsystems.com).

Hydrogen, supplied from a pressurized cylinder, is sent through the heated anode humidifier before being fed to the anode side of the fuel cell. Oxidant with any desired composition (oxygen in nitrogen) is supplied from a pressurized cylinder and sent to the heated cathode humidifier before being fed to the cathode side of the fuel cell. Constant volumetric flow rates for anode and cathode feeds are manually controlled by rotameters. Humidification of the feed streams is necessary to maintain conductivity of the electrolyte membrane. Heating of the humidifiers and pre-heating of the fuel cell is accomplished using heating tape and temperatures of the feed streams and fuel cell are maintained using temperature controllers. To avoid flooding the catalyst structure, the humidifier temperature is maintained at or below the cell temperature. Effluent from the fuel cell is vented for safety purposes.

Figure 3. Schematic of Experimental Setup

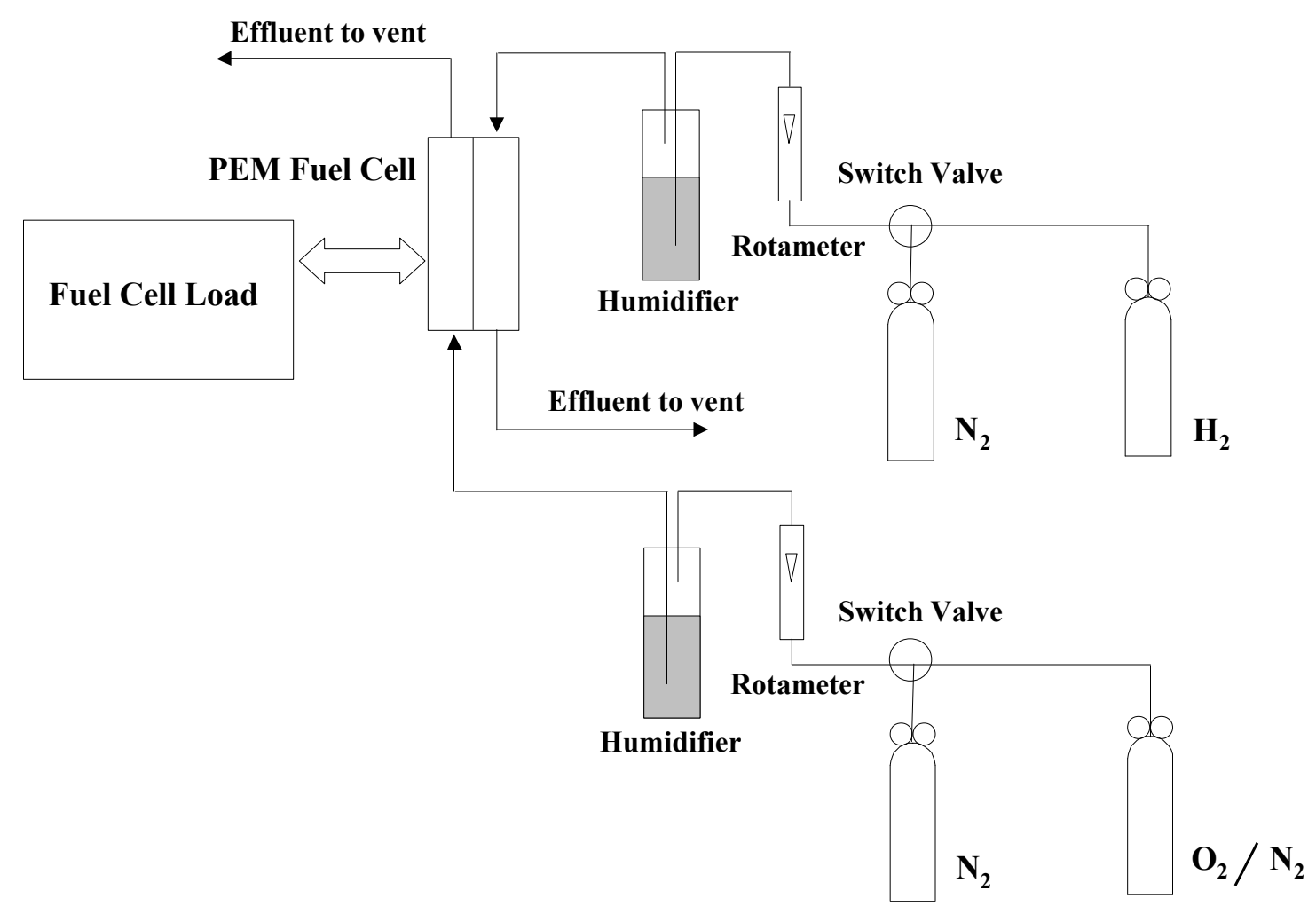

Our fuel cell load and output electronics are integrated in a test stand manufactured by Scribner Associates. During a typical experimental run (constant flow rate, oxidant composition and 
temperature), the current is manipulated/adjusted on the fuel cell load and the voltage and resistance are read from a built-in meters in the load.

The PEM fuel cell was comprised of an MEA with active area of $5 \mathrm{~cm}^{2}$ (prepared at the University of Connecticut) and housed in a single cell with a single-pass serpentine flow channel. MEA's and single cell hardware are commercially available from Electrochem, Lynntech, Fuel Cell Technology and Gore.

\section{Procedure}

A fuel cell with a prepared or commercial MEA is first connected to the fuel cell test system. Before feeding hydrogen and oxidant into the fuel cell, humidified nitrogen is introduced to purge the anode and cathode sides of the single cell. During the purge (at $50 \mathrm{cc} / \mathrm{min}$ ), the cell and humidifiers are heated to their respective operating temperatures (e.g. cell $=80^{\circ} \mathrm{C}$, humidifiers $=80^{\circ} \mathrm{C}$ ). When the cell and humidifiers reach the desired temperature, the humidified nitrogen is replaced by humidified hydrogen and oxidant for the anode and cathode, respectively. Fuel and oxidant are always fed in excess of the amount required to produce a current of $1000 \mathrm{~mA}$ as calculated by Faraday's Law. The hydrogen and oxidant flow rates used in these experiments are based on operating at $200-300 \%$ excess. After introducing the fuel and oxidant into the cell, the open circuit voltage (zero current) should be between 0.8 and 1 volt. Fuel cell performance curves are generated by recording steady state voltage at different currents. Note that current density is obtained by dividing the current by the cell area $\left(5 \mathrm{~cm}^{2}\right)$. Approximately 5 minutes is required to reach steady state for changes in current at constant composition and temperature, however, it might take 20-30 minutes to reach steady state for a change in either oxidant composition or temperature. The system should be purged with nitrogen during shutdown.

\section{Implementation}

This experiment will be included as part of a three credit senior-level chemical engineering undergraduate laboratory at the University of Connecticut in the Spring 2003. The course consists of two 4-hour labs per week during which groups of 3 to 4 students perform experiments on five different unit operations throughout the semester (e.g. distillation, heat exchanger, gas absorption, batch reactor, etc.). Each unit is studied for either one or two weeks, depending on the complexity and scale of the equipment. Given only general goals for each experiment, students are required to define their own objectives, develop an experimental plan, give a pre-lab report including a discussion of safety considerations, perform the experiments, analyze the data and prepare group or individual written and/or oral reports. Due to their similar nature and focus (generation of performance/characteristic curves and analysis of efficiency at various operating conditions), the fuel cell experiment is expected to replace the existing centrifugal pump experiment.

\section{Results and Discussion}

\section{Performance}

Performance curves (voltage vs. current density) and membrane resistance at $80{ }^{\circ} \mathrm{C}$ with different oxidant compositions (pure oxygen, air, $10.5 \% \mathrm{O}_{2}$ in $\mathrm{N}_{2}$ and $5.25 \% \mathrm{O}_{2}$ in $\mathrm{N}_{2}$ ) are shown in Figure 4. Activation polarization (kinetic limitation) is observed at very low current density (0$150 \mathrm{~mA} / \mathrm{cm}^{2}$ ). Kinetic losses increase with a decrease in oxygen concentration. At low current 
densities, membrane resistance (ohmic polarization) is nearly constant $\left(\approx 0.14 \Omega-\mathrm{cm}^{2}\right)$ and is independent of oxidant composition. Membrane resistance begins to increase slightly with increasing current density at $800 \mathrm{~mA} / \mathrm{cm}^{2}$ due to dry-out of the membrane on the anode side. Dry-out occurs at high current density because water molecules associated with migrating protons are carried from the anode side to the cathode at a higher rate than they can diffuse back to the anode. Mass transport limitations due to insufficient supply of oxygen to the surface of catalyst at high current density is observed, especially for gasses containing low concentrations of oxygen. Limiting currents are clearly evident at $340 \mathrm{~mA} / \mathrm{cm}^{2}$ and $680 \mathrm{~mA} / \mathrm{cm}^{2}$ for the $5.25 \%$ and $10.5 \%$ oxygen gasses, respectively. Limiting current density for pure oxygen and air are not obvious from the data.

Figure 4.

Effect of Oxidant Concentration on Cell Performance and Membrane Resistance

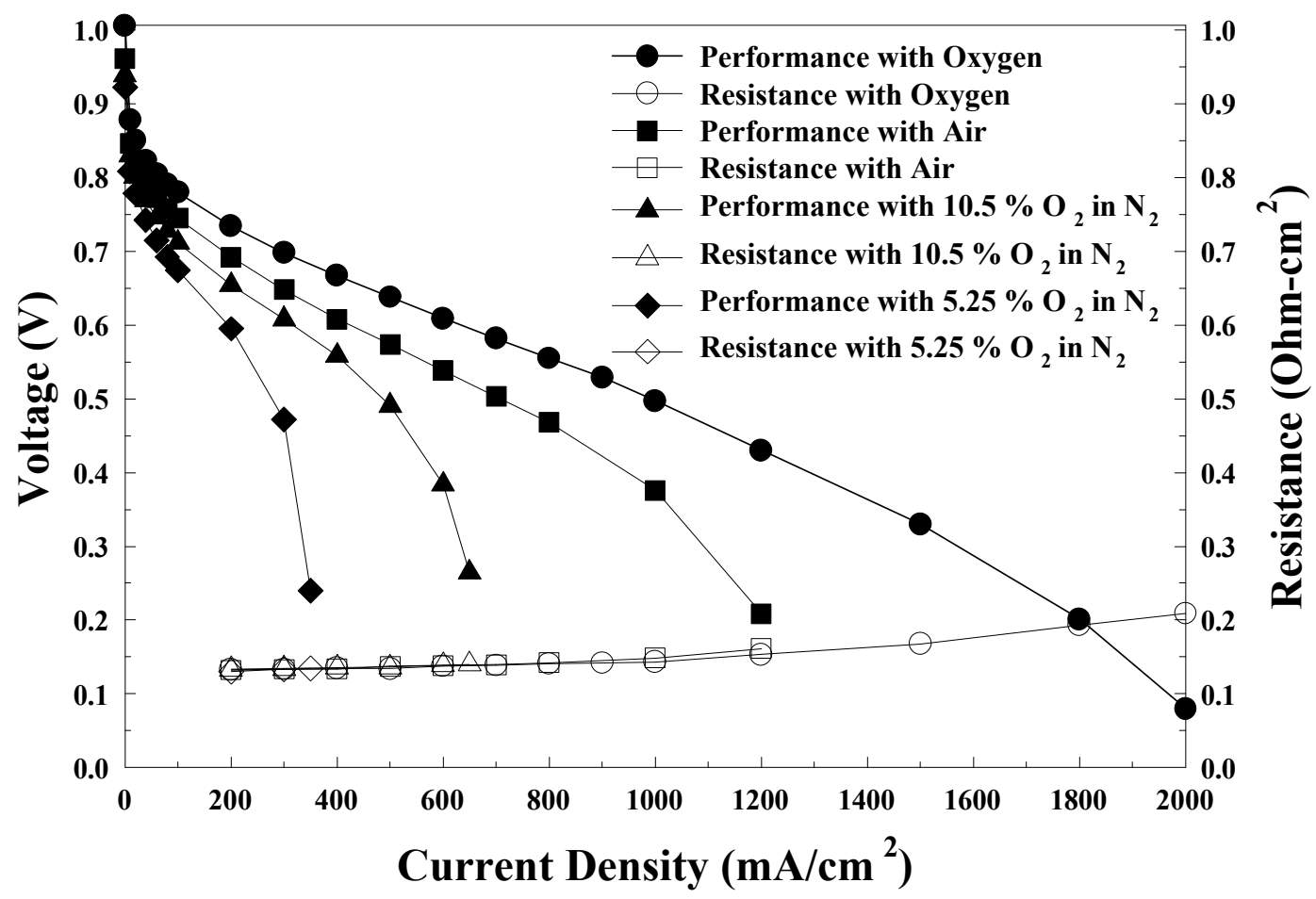

The effect of operating temperature $\left(18{ }^{\circ} \mathrm{C}\right.$ vs. $80{ }^{\circ} \mathrm{C}$, both at $100 \%$ relative humidity $)$ on cell performance and membrane resistance for a pure $\mathrm{O}_{2} / \mathrm{H}_{2}$ cell is shown in Figure 5. At elevated temperature, fast kinetics on the surface catalyst and lower membrane resistance result in better cell performance. Under fully hydrated environments $(100 \% \mathrm{RH})$, membrane resistance decreases with increasing temperature due to increased mobility of the protons. Again, limiting current density for pure oxygen is not obvious in this plot. 
Figure 5.

Effect of Temperature on Cell Performance and Membrane Resistance

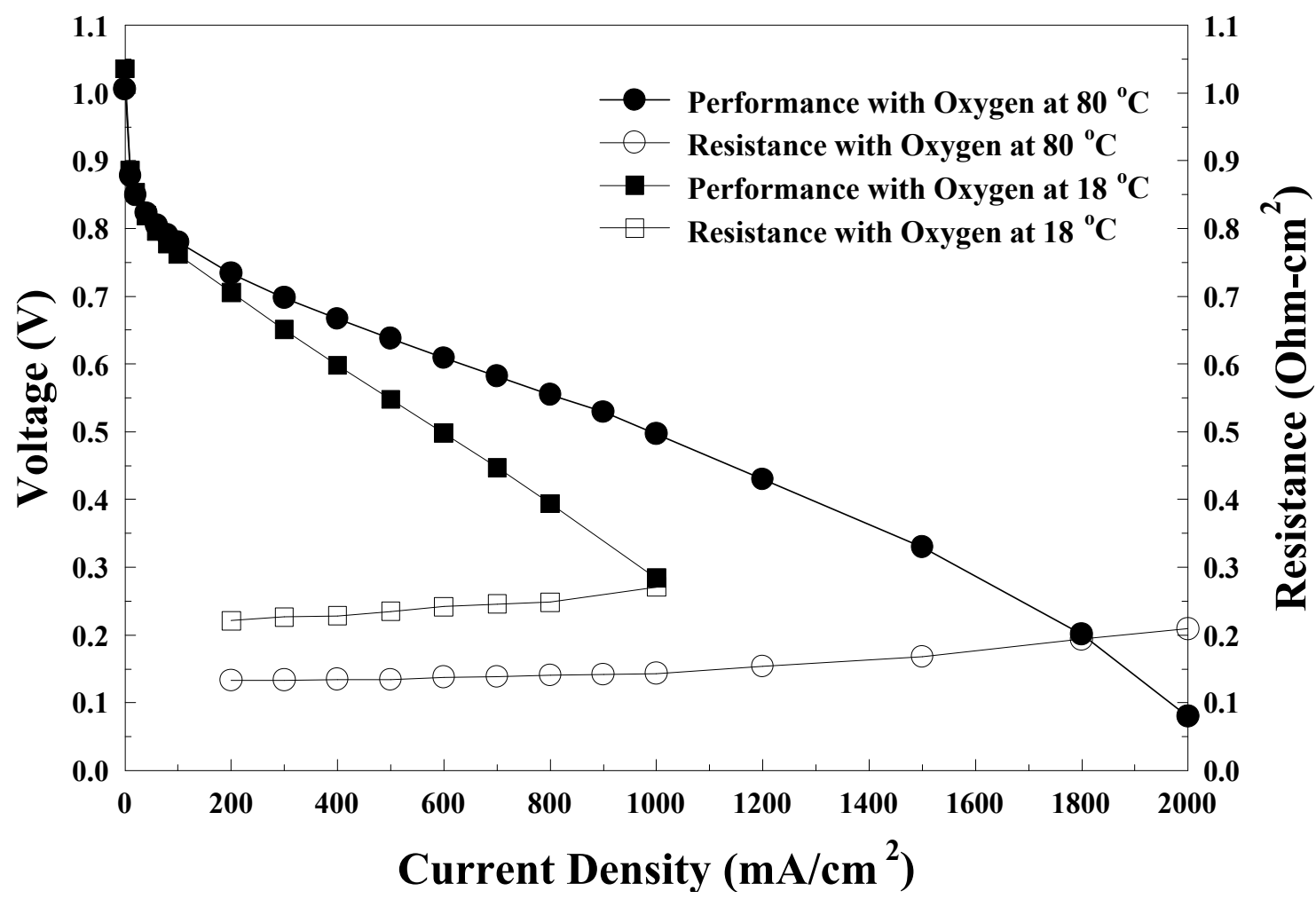

Empirical Model

Although comprehensive modeling of a fuel cell system is beyond the scope of an undergraduate lab, a simple model describing voltage-current characteristics of the fuel cell can be introduced to the students and tested for 1) its ability to fit the data and 2) its usefulness as an analytical tool. The following empirical model describing the loss of cell voltage due to kinetic, ohmic, and transport limitations was proposed by Srinivasan et al. ${ }^{[8]}$ :

$$
\mathrm{V}=\mathrm{E}-(\mathrm{B} \log (\mathrm{i})-\mathrm{A})-\mathrm{iR}-\mathrm{m} \exp (\mathrm{ni})
$$

Lumping E and A together gives

$$
\mathrm{V}=\mathrm{E}+\mathrm{A}-(\mathrm{B} \log (\mathrm{i}))-\mathrm{iR}-\mathrm{m} \exp (\mathrm{ni})
$$

Equation (6) is modeled after Equation (4) assuming the anode polarization terms in Equation (4) are negligible, that the kinetic limitations of the cathode can be described by the Tafel Equation (3), and that mass transport losses can be fit using the parameters $\mathrm{m}$ and $\mathrm{n}$. 
Figure 6 shows the model fit to experimental data using nonlinear regression software $\left(\right.$ Polymath $^{\mathrm{TM}}$ ). All curves generated using this model have correlation coefficients in excess of 0.999. The model therefore is excellent as a fitting function for fuel cell performance curves from which values can be interpolated or extrapolated. This is particularly handy for estimating limiting current density in cases where the data is insufficient (such as the pure oxygen curves shown above).

Figure 6.

Non-Linear Regression Fit of Experimental Data

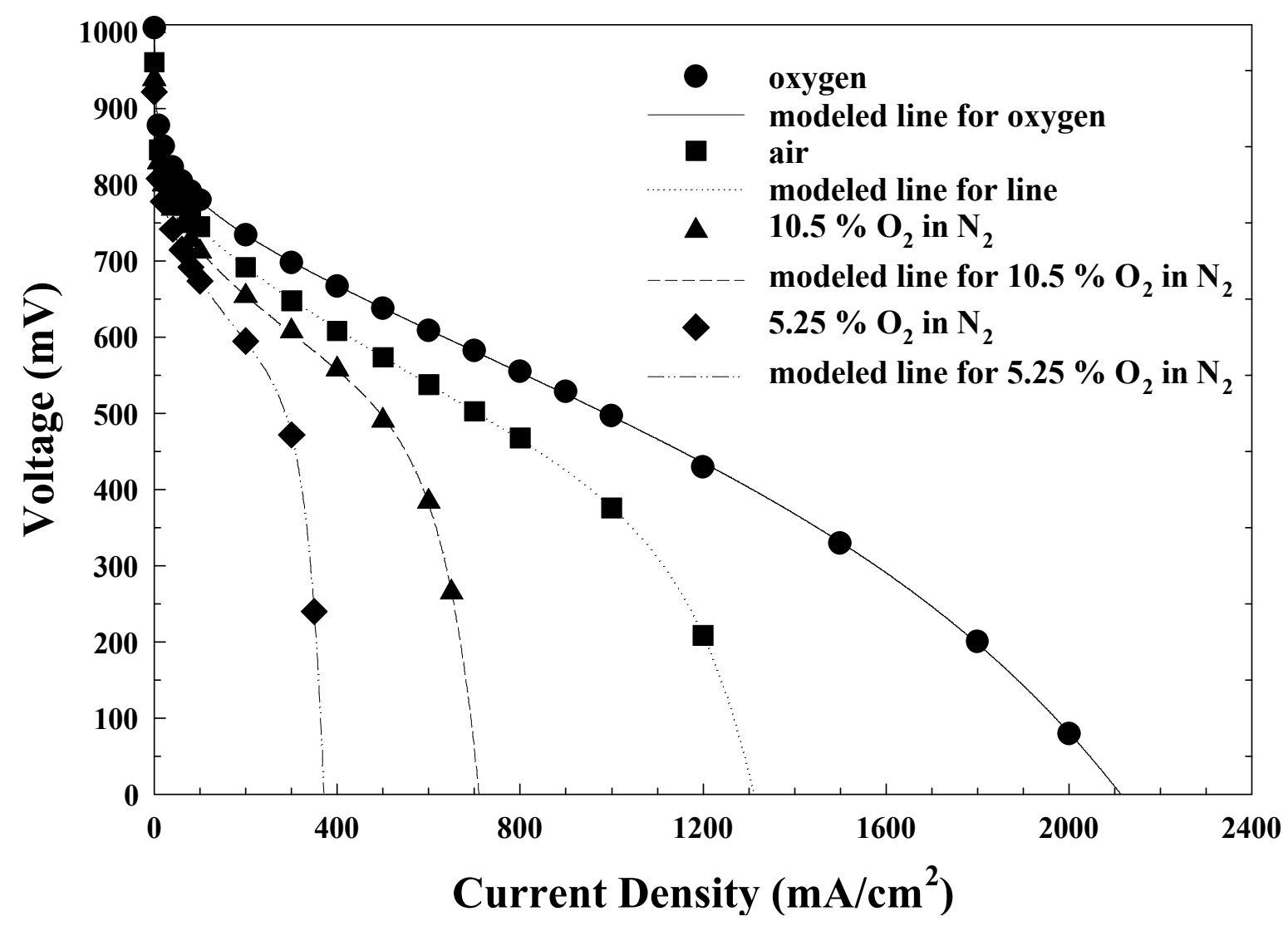

Values for the adjustable parameters $([\mathrm{E}+\mathrm{A}], \mathrm{B}, \mathrm{R}, \mathrm{m}, \mathrm{n})$ calculated by the regression software are summarized in Table 2. The "regression generated" values for R can be compared to experimentally measured values (shown on the right hand scale of Figures $4 \& 5$ ) and "regression generated" values for B can be compared to those predicted using theory. In this way the model can be tested for its "analytical" capability.

Contrary to experimental results, resistance calculated using Equation (6) increases with decreasing oxygen concentration and is $40 \%-200 \%$ higher than measured membrane resistance (0.14-0.16 $\left.\Omega-\mathrm{cm}^{2}\right)$. While this may suggest that $\mathrm{R}$ from Equation (6) includes voltage losses other than the ohmic resistance of the membrane, it is more likely that the model is not reliable in predicting true physical behavior of individual contributions to the polarization curve. 
Table 2.

Best Fit Values for Kinetic Parameters, Ohmic Losses, and Transport Parameters Obtained Using Equation (6).

\begin{tabular}{|c|c|c|c|c|c|c|c|c|c|}
\hline $\begin{array}{c}\text { Oxidant } \\
\text { Comp }\end{array}$ & $\begin{array}{c}\mathbf{T e m p} \\
\left({ }^{\mathbf{}} \mathbf{C}\right)\end{array}$ & $\begin{array}{c}\mathbf{E}+\mathbf{A} \\
(\mathbf{m v})\end{array}$ & $\begin{array}{c}\mathbf{B}_{\text {fit to eqn 6 }} \\
(\mathbf{m v} / \mathbf{d e c})\end{array}$ & $\begin{array}{c}\mathbf{B}_{\text {fit to eqn 3 }} \\
(\mathbf{m v} / \mathbf{d e c})\end{array}$ & $\begin{array}{c}\mathbf{R}_{\text {fit to eqn 6 }} \\
\left(\Omega-\mathbf{c m}^{2}\right)\end{array}$ & $\begin{array}{c}\mathbf{R}_{\text {measured }} \\
\left(\Omega-\mathbf{c m}^{2}\right)\end{array}$ & $\begin{array}{c}\mathbf{m} \\
(\mathbf{m v})\end{array}$ & $\begin{array}{c}\mathbf{n} \\
\left(\mathbf{c m}^{2} / \mathbf{m A}\right)\end{array}$ & $\begin{array}{c}\text { Correlation } \\
\text { Coefficient } \\
\left(\mathrm{R}^{\wedge} 2\right)\end{array}$ \\
\hline Oxygen & 80 & 963 & 79 & 85 & 0.20 & $\begin{array}{c}0.14- \\
0.16\end{array}$ & 4.202 & 0.0020 & 0.999 \\
\hline Air & 80 & 927 & 77 & 84 & 0.29 & $\begin{array}{c}0.14- \\
0.16\end{array}$ & 0.018 & 0.0074 & 0.999 \\
\hline $\begin{array}{c}10.5 \% \\
\mathrm{O}_{2} \text { in } \\
\mathrm{N}_{2}\end{array}$ & 80 & 921 & 87 & 94 & 0.33 & $\begin{array}{c}0.14- \\
0.16\end{array}$ & 0.035 & 0.0133 & 0.999 \\
\hline $\begin{array}{c}5.25 \% \\
\mathrm{O}_{2} \text { in } \\
\mathrm{N}_{2}\end{array}$ & 80 & 902 & 88 & 95 & 0.51 & $0.14-$ & 0.008 & 0.0297 & 0.999 \\
\hline
\end{tabular}

Equation (6): $V=E+A-(B \log (i))-i R-m \exp (n i)$

Equation (3): $\quad \eta_{\text {act }}=B \log |\mathrm{i}|-\mathrm{A}$

Theoretical Tafel slope, $\mathrm{B}$, is equal to $2.303 \mathrm{RT} / \alpha \mathrm{F}$ where $\mathrm{R}$ is the Ideal Gas constant and $\alpha$ is a lumped kinetic parameter equal to 1 for the oxygen reduction reaction occurring on the cathode $^{[6]}$. According to this theory, the Tafel slope should be about $70 \mathrm{mv} /$ decade at $80^{\circ} \mathrm{C}$. Table 2 shows the regression generated B is $20-36 \%$ higher than the value of $70 \mathrm{mv} / \mathrm{dec}$ ade. Again, one might suggest some physical reasons for this discrepancy such as the existence of diffusion or resistive losses in the cathode catalyst layer of the electrode. However, we may argue that the model is too "flexible" to assign any significance to the values of the "fit" parameters (i.e. a huge range of values for each parameter will yield a good fit). Tafel slopes are more accurately obtained from raw data using the Tafel Equation (Eqn 3). In this case B can be found by plotting $i R$-free voltage $(V+i R) v s . \log i$ and measuring the slope of the line in the kinetically controlled portion of the plot (at low values of $\log$ i). Values for B found using this technique have been included in Table 2 .

The parameters $\mathrm{m}$ and $\mathrm{n}$ are intended to describe mass transport limitations but actually have no physical basis. One might expect these parameters to be dependent on flow characteristics in the cell that were not investigated in this study. Therefore, we can make no statement about the predictive or analytical usefulness of $\mathrm{m}$ and $\mathrm{n}$.

To confirm the premise that the model is too flexible to be used for analyzing individual contributions to the voltage loss, sensitivity studies can be performed. For instance, model sensitivity to Tafel slope can be observed by keeping all parameters constant except B (eg. $\left.[\mathrm{E}+\mathrm{A}]=902 \mathrm{mv}, \mathrm{R}=0.51 \Omega-\mathrm{cm}^{2}, \mathrm{~m}=.008 \mathrm{mv}, \mathrm{n}=0.0297 \mathrm{~cm}^{2} / \mathrm{mA}, \mathrm{B}=70,80,90,100 \mathrm{mv} / \mathrm{dec}\right)$. Generally, large changes in individual coefficients have only a small effect on the model fit as shown in Table 3. Therefore, the model cannot be used to analyze individual contributions to the 
polarization curve with confidence. It should be noted that for research purposes, a true difference in Tafel slope of $10 \mathrm{mv} / \mathrm{dec}$ is significant.

Table 3.

Model Sensitivity to Changes in the Value of the Tafel Slope

\begin{tabular}{|c|c|c|c|}
\hline $\begin{array}{c}\text { Oxidant } \\
\text { Composition }\end{array}$ & Set parameter values & $\begin{array}{c}\text { B } \\
\text { (mv/dec) }\end{array}$ & $\begin{array}{c}\text { Correlation } \\
\text { Coefficient (R 2) }\end{array}$ \\
\hline $5.25 \% \mathrm{O}_{2}$ in $\mathrm{N}_{2}$ & {$[\mathrm{E}+\mathrm{A}]=902 \mathrm{mv}$} & 70 & 0.999 \\
& $\mathrm{R}=0.51 \Omega-\mathrm{cm}^{2}$ & 80 & 0.999 \\
& $\mathrm{~m}=.008 \mathrm{mv}$ & 90 & 0.999 \\
& $\mathrm{n}=0.0297 \mathrm{~cm}^{2} / \mathrm{mA}$ & 100 & 0.982 \\
\hline
\end{tabular}

\section{Summary}

Fuel cell based experiments embody principles in electrochemistry, thermodynamics, kinetics and transport and are well suited for the chemical engineering curricula. Students are given an opportunity to familiarize themselves with fuel cell operation and performance characteristics by obtaining voltage versus current density data for the unit at varying oxidant compositions and temperatures. A simple model can be used as a fitting function for interpolation and extrapolation purposes. Model sensitivity analysis can be performed to evaluate its usefulness as an analytical tool. The lab can be completed easily in two 4-hour lab periods. The experiment is also suitable for use as a demonstration in a typical lecture course or as a hands-on project for high school students and teachers.

\section{Bibliography}

1. Thomas, S. and M. Zalbowitz, "Fuel Cells-Green Power”, Los Alamos National Laboratory, LA-UR-99-3231 (1999).

2. Larminie, J. and A. Dicks, Fuel Cell Systems Explained, John Wiley \& Sons, (2000).

3. Hoogers, G., Fuel Cell Technology Handbook, 1st ed, CRC Press, (2002).

4. Hirschenhofer, J. H., D. B. Stauffer, R. R. Engleman, and M. G. Klett, "Fuel Cell Handbook," Fifth Edition, National Technical Information Service, U. S. Department of Commerce, VA (2000).

5. Koppel, T. and J. Reynolds, A Fuel Cell Primer: The Promise and the Pitfalls, downloadable PDF file available at www.fuelcellstore.com/cgi-bin/fuelweb/view=item/cat=18/subcat=19/product=20.

6. Prentice, G., Electrochemical Engineering Principles, Prentice Hall, New Jersey, (1991).

7. Bard, A.J. and L. Faulkner, Electrochemical Methods; Fundamentals \& Applications, 2nd ed., John Wiley \& Sons, (2000).

8. Kim, J., S-M. Lee, and S. Srinivasan, "Modeling of Proton Exchange Membrane Fuel Cell Performance with an Emprical Equation,” J. Electrochem. Soc., 142(8), 2670 (1995).

\section{JUNG-CHOU LIN}

Jung-Chou Lin earned his Ph.D. from the University of Connecticut and his B.S. from the Tunghai University, Taiwan, both in chemical engineering. After graduation, he was employed as an Assistant Professor in Residence to develop fuel cell experiments for the undergraduate laboratory by University of Connecticut. Currently, Dr. Lin 
is a senior Research Engineer at Microcell Corporation, Raleigh, North Carolina. His research interests are in the areas of catalysis, electrochemical engineering and fuel cells.

\section{H. RUSSEL KUNZ}

H. Russel Kunz is Professor-in-Residence in the Chemical Engineering Department at the University of Connecticut and Director of Fuel Cell Laboratories at the University of Connecticut. An internationally recognized expert in fuel cell development, Dr. Kunz was educated at Rensselaer Polytechnic Institute, receiving his B.S. and M.S. degrees in Mechanical Engineering and his Ph.D. in Heat Transfer. Prior to joining the Chemical Engineering Department, Dr. Kunz worked for many years at International Fuel Cells (IFC) in theoretical and experimental fuel cell research.

JAMES M. FENTON

James M. Fenton is Professor of Chemical Engineering at the University of Connecticut. He teaches Transport Phenomena and Senior Unit Operation Laboratory courses. His research interests are in the areas of electrochemical engineering and fuel cells. Dr. Fenton earned his Ph.D. from the University of Illinois and his B.S. from the University of California, Los Angeles, both in chemical engineering.

\section{SUZANNE S. FENTON}

Suzanne S. Fenton is the Assistant Department Head and Visiting Assistant Professor of Chemical Engineering at the University of Connecticut. She teaches Transport Phenomena and Senior Unit Operations Laboratory courses and provides innovative instruction for secondary school students. Dr. Fenton received her B.S. degree in Environmental Engineering from Northwestern University and Ph.D. in Chemical Engineering from the University of Illinois. 